\title{
Hydration behavior of iron doped calcium sulfoaluminate phase at room temperature
}

\author{
M. Idrissi ${ }^{1}$, A. Diouri ${ }^{1}$, M. Alami Talbi ${ }^{1}$, O. Sassi $^{2}$, M. Taibi ${ }^{2}$ and D. Damidot ${ }^{3}$ \\ 1: Laboratoire de Chimie du Solide Appliquée, Faculté des Sciences, Université MohammedV-Agdal, 10000 \\ Rabat, Maroc. \\ 2: Laboratoire de Physico-chimie des Matériaux, Ecole Normale Supérieure, Rabat, Maroc. \\ 3: Département de Génie Civil et environnemental, Ecole des Mines de Douai, 941 Rue Charles Bourseul, 59500 \\ Douai, France
}

\begin{abstract}
Different samples of calcium sulfoaluminate phase doped with iron, $\left(\mathrm{Ca}_{4} \mathrm{Al}_{(6-2 \mathrm{x})} \mathrm{Fe}_{2 \mathrm{x}} \mathrm{SO}_{16}\right)$ with $\mathrm{x}=0,0.2$ and 0.5 , were synthesized at $1350^{\circ} \mathrm{C}$. The hydration kinetics of the resulted phases was investigated by calorimetric and conductimetric techniques. The hydrated samples were analyzed by X-ray diffraction and scanning electron microscopy. The hydration of calcium sulfoaluminate was slightly modified by inclusion of iron in its structure. Dissolution rate of calcium sulfoaluminate phase doped with iron appeared to be slowed down such as the nucleation rate during the induction period while the percentage of reaction after 1 day was slightly increased. The analysis of hydrates indicated the formation of the same hydrates, ettringite and calcium monosulfoaluminate and the gibbsite, with or without iron replacement. Gibbsite played a major role in the kinetics of the induction period and thus the presence of iron may decrease its nucleation rate forming $(\mathrm{A}, \mathrm{F}) \mathrm{H}_{3}$ instead of $\mathrm{AH}_{3}$.
\end{abstract}

\section{Introduction}

The mineral phase, calcium sulfoaluminate also named as Ye'elimite $\left(\mathrm{C}_{4} \mathrm{~A}_{3} \mathrm{~S}\right)$, has been known as hydraulic phase for several decades, but its potential in non expansive cementitious materials has only recently been reported. As a result of many researches, an optimized formulation based on a clinker containing $\mathrm{C}_{4} \mathrm{~A}_{3} \mathrm{~S}$, belite $\left(\mathrm{C}_{2} \mathrm{~S}\right)$, ferrite $\left(\mathrm{C}_{4} \mathrm{AF}\right)$ and anhydrite $\left(\mathrm{CaSO}_{4}\right)$ was developed [1]. Industrial calcium sulfoaluminate cements have essentially been developed from natural resources (calcium carbonate, gypsum, and bauxite) [2-8]. Productions of several variants of this basic clinker are being manufactured, leading to different properties such as high early strength. The most promising phase of these cement, is the calcium sulfoaluminate $\mathrm{Ca}_{4} \mathrm{Al}_{6} \mathrm{SO}_{16}\left(\mathrm{C}_{4} \mathrm{~A}_{3} \mathrm{~S}\right)$ that can be easily formed above $1200^{\circ} \mathrm{C}$ and that is stable up to $1400^{\circ} \mathrm{C}$. As a consequence, the clinkerization temperature of this type of cement is low $\left(1200-1250^{\circ} \mathrm{C}\right)$ compared to Ordinary Portland Cement $\left(1400-1450{ }^{\circ} \mathrm{C}\right)$. It is thus currently attracting a great deal of interest worldwide [9, 10]. Its advantages include: i) reduced energy consumption during manufacturing, ii) low $\mathrm{CO}_{2}$ emission during manufacturing [11], iii) low alkalinity, iv) acceptable setting times and high-early strength development, [12], v) very good durability, particularly in marine construction [8].

Calcium sulfoaluminate can include in its structure a number of impurities, such us $\mathrm{Ti}^{4+}, \mathrm{Cr}^{3+}, \mathrm{Mn}^{3+}, \mathrm{Fe}^{3+}, \mathrm{Si}^{4+}$, etc. The hydration of this phase has been extensively studied in the past [13-16]. The required water/cement ratio for complete hydration is higher compared to the Portland cement, e. g. 0.78 for pure ye'elimite reacting with 2 mol of anhydrite [17]. In comparison to Portland cement, cements based on calcium sulfoaluminate react faster, and most of the hydration heat evolution occurs between 2 and $12 \mathrm{~h}$ of hydration [18]. The hydration products are mainly ettringite $\left(3 \mathrm{CaO} \cdot \mathrm{Al}_{2} \mathrm{O}_{3} \cdot 3 \mathrm{CaSO}_{4} \cdot 32 \mathrm{H}_{2} \mathrm{O}\right)$ and alumina gel $\left(\mathrm{Al}_{2} \mathrm{O}_{3} \cdot \mathrm{nH}_{2} \mathrm{O}\right)$ but calcium monosulfoaluminate hydrate $\left(3 \mathrm{CaO} \cdot \mathrm{Al}_{2} \mathrm{O}_{3} \cdot \mathrm{CaSO}_{4} \cdot 12 \mathrm{H}_{2} \mathrm{O}\right)$ can also be present depending on the level of calcium sulfate addition. Indeed this last phase is formed when sulfate ions are depleted from the aqueous phase [8].

Thus the quantities of ettringite, gibbsite and calcium monosulfoaluminate hydrate depend upon the relative proportions of $\mathrm{C}_{4} \mathrm{~A}_{3} \mathrm{~S}, \mathrm{CS}$, and $\mathrm{H}_{2} \mathrm{O}$ in the cement paste. Microstructural investigations [18, 19] revealed mainly the formation of large space filling ettringite needles, together with calcium monosulfoaluminate hydrate, aluminium hydroxide and calcium silicate hydrates (coming from $\mathrm{C}_{2} \mathrm{~S}$ ), and leading to a dense microstructure. 
The calcium sulfoaluminate cement are very interesting from the environmental point of view, due to the utilization of wastes and by products as fluidized bed combustion wastes and low-quality pulverized coal fly ashes and flue gas desulphurization gypsum [20].

The iron distribution among the sulfoaluminate clinker phases and its ability to enter the calcium sulfoaluminate lattice in solid solution can have a significant influence on manufacturing process and on reactivity of calcium sulfoaluminate (CSA) cements. Indeed the inclusion of iron in Ye'elimite induced a deficiency of calcium and showed small variations in the values of the cell parameters [21]. Moreover the synthesis of $\mathrm{Ca}_{4} \mathrm{Al}_{(6-2 \mathrm{x})} \mathrm{Fe}_{2 \mathrm{x}} \mathrm{SO}_{16}$, with $\mathrm{x}$ increasing from 0 to 1.5 , showed that both the iron content of $\mathrm{C}_{4} \mathrm{~A}_{3} \mathrm{~S}$ phase and the amounts of side components such as $\mathrm{C}_{2} \mathrm{~F}$ and $\mathrm{CS}$ increased. Under the experienced conditions, the maximum iron concentration in the calcium sulfoaluminate phase was $21.5 \mathrm{wt} \%$. According to Krivoborodov et al. [22], the hydration rate during the first three days falls with the increasing of (iron/alumina) ratio but later it becomes equal to the hydration rate of the none iron substituted calcium sulfoaluminate. Nevertheless in this study, it is not possible to assess the effect of iron entering into Ye'elimite to the increase of $\mathrm{C}_{2} \mathrm{~F}$ phase relatively to the decrease of Ye'elimite. The aim of the present work was to investigate the effect of iron substitution on the hydration at room temperature of $\mathrm{Ca}_{4} \mathrm{Al}_{(6-2 x)} \mathrm{Fe}_{2 \mathrm{x}} \mathrm{SO}_{16}$ at moderate concentrations of iron, $\mathrm{x}=0.2,0.5$ for which most of the iron enters Ye'elimite compared to pure Ye'elimite. Hydration kinetics was followed by isothermal calorimetry on paste and electrical conductivity on diluted and stirred suspensions. Hydration products were analyzed by $\mathrm{X}$ ray diffraction and scanning electron microscopy.

\section{Experimental methods}

The samples were synthesized from stoechiometric amounts of reagent grade $\mathrm{CaCO}_{3}, \mathrm{Al}_{2} \mathrm{O}_{3}, \mathrm{Fe}_{2} \mathrm{O}_{3}$ and $\mathrm{CaSO}_{4} \cdot 2 \mathrm{H}_{2} \mathrm{O}$ with $>99 \%$ purity and thermally treated in laboratory furnace between $1300{ }^{\circ} \mathrm{C}$ and $1350{ }^{\circ} \mathrm{C}$ by steps of $200{ }^{\circ} \mathrm{C}$, with an intermediate grinding in order to increase the homogeneity, the clinker so prepared was cooled overnight in the furnace to room temperature [21]. $\mathrm{Ca}_{4} \mathrm{Al}_{(6-2 \mathrm{x})} \mathrm{Fe}_{2 \mathrm{x}} \mathrm{SO}_{16}$ mixtures have been named $\mathrm{SX}$ with $\mathrm{X}$ equal 10 times $\mathrm{x}$. In this study S00, S02 and S05 mixtures have been studied as only Ye'elimite containing some iron is present after the synthesis. Nevertheless the iron amount in Ye'elimite increases accordingly to the initial iron amount.

Hydration was carried out in distilled water with a W/C ratio of 0.5 and 20 respectively for calorimetric and electrical conductivity measurements. For calorimetry, the measurements were carried out during 1 day at $21^{\circ} \mathrm{C}$ using a sample weight of $0.5 \mathrm{~g}$. The total heat of hydration after 1 day was determined by integration of the heat flow curve. The electrical conductivity was measured on a stirred suspension using a device specially developed by CAD (CDM210). The suspension having a volume of $100 \mathrm{ml}$ is thermostated in order to keep the temperature constant and equal to $20^{\circ} \mathrm{C}$ during the experiments.

The hydrated sample was removed from the calorimeter, washed with acetone and heated at $60^{\circ} \mathrm{C}$ for $3 \mathrm{~h}$. Then the dried pastes named SXH with $\mathrm{X}=0,0.2$ and 0.5 , were analyzed by XRD using Bruker D8 ADVANCE (CoKa radiation) $X$-ray diffractometer in a scanning range of $5^{\circ}$ to $60^{\circ}$ in $2 \theta$ scale. The step rate that was applied was $0.02 \% \mathrm{~min}$ for all specimens. The identification of the phases was carried out by using the EVA analysis software (C) 2005 Bruker AXS). The dried pastes were also observed using a XL 30 Philips SEM equipped with an energy-dispersive X-ray analyzer (EDAX).

\section{Results and discussions}

\subsection{Calorimetry}

The influence of the iron doping Ye'elimite on the heat flow evolution during the hydration of the samples is shown in figure. 1. In absence of iron, the pure Ye'elimite phase corresponding to S00, shows two maxima in the heat flow curve. The first occurs directly when the water is added and can be attributed to heat of wetting and very early hydration reactions. After that, a period of very low heat flux release called induction period is observed during about $6 \mathrm{~h}$. This result is in agreement with thus obtained by F.Winnefeld and al. [23] that observed an induction period of about $10 \mathrm{~h}$ for Ye'elimite hydrated at $20^{\circ} \mathrm{C}$. Nevertheless in our case, the duration of the induction period is shorter due to the temperature that is of $21^{\circ} \mathrm{C}$ and not $20^{\circ} \mathrm{C}$ and may be a different specific surface area. Indeed an increase of temperature appears to markedly reduce the induction period that only lasts $2 \mathrm{~h}$ at $25^{\circ} \mathrm{C}$ [24]. Several hypotheses have been made to explain the induction period and its duration but none is completely satisfactory. Amongst these, one can consider a surface coverage of Ye'elimite grains by the early hydration products but also some difficulty of nucleation of one or more of these early hydrates. After the induction period, the heat flow increased again, reaching a second maximum after about $10 \mathrm{~h}$ of hydration. This peak covers the main part of the hydration reactions and is responsible for setting and hardening of the paste. Beyond the maximum, the heat flow decreased without showing any other maximum or shoulder in the heat flow curve. These results are in good agreement to the other research [23]. 


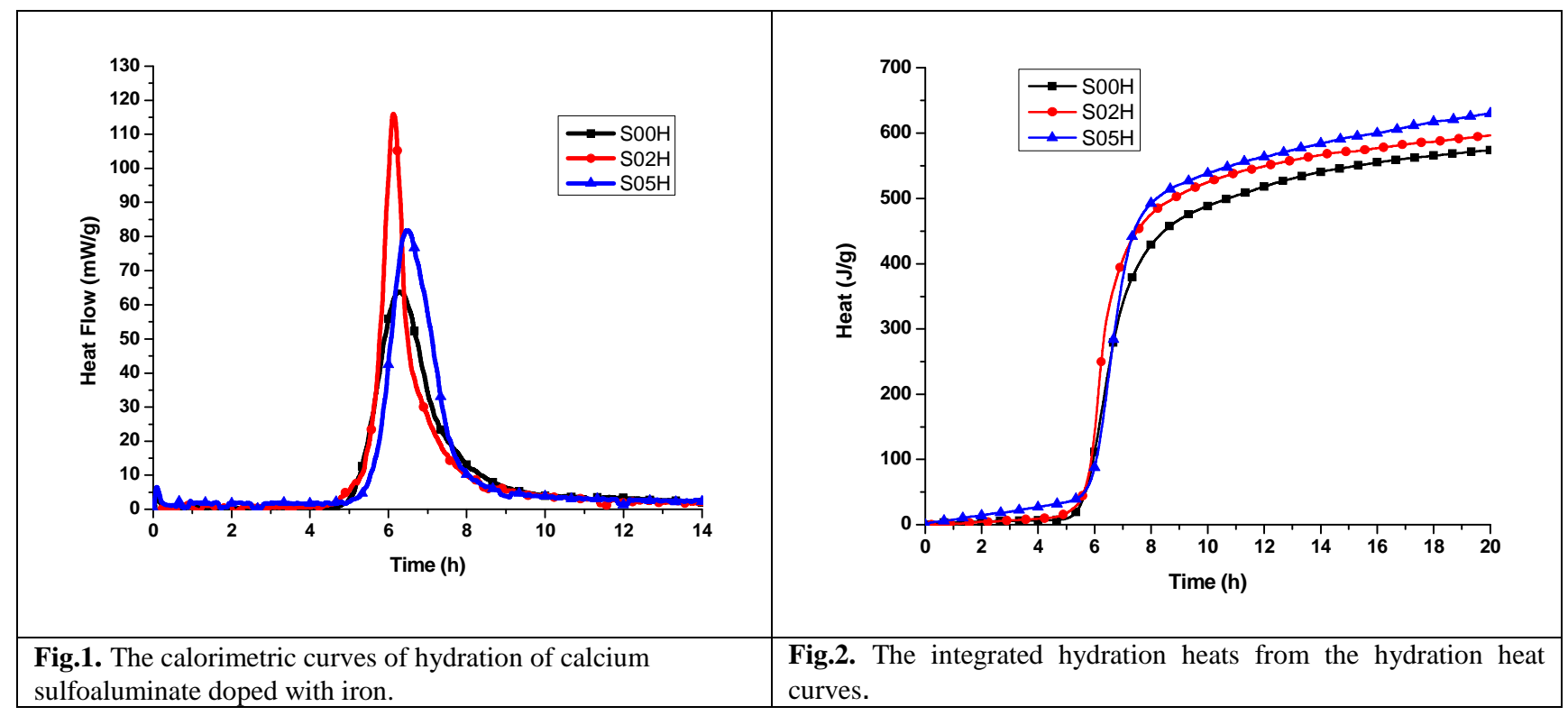

The heat flow curves corresponding to iron doping in calcium sulfoaluminate phase showed a similar behaviour compared to pure calcium sulfoaluminate phase despite some difference with respect to the kinetics during the main part of hydration. Indeed the main hydration peak is sharper for S02 compared to S00 and flatter for S05. However the total heat released increased slightly by increasing the iron content in the sample, e.g $550 \mathrm{~J} / \mathrm{g}$ for $\mathrm{S} 00 \mathrm{H}$ to $650 \mathrm{~J} / \mathrm{g}$ for S05H (Figure 2).

\subsection{Electrical Conductivity}

The evolution of the electrical conductivity for the different mixtures is represented in Figure 3. If Ye'elimite is considered first, the initial hydration of this phase corresponds to the initial increase of electrical conductivity. This initial increase in electrical conductivity is followed by a steady decline which describes the induction period characterized by a slower reaction rate during which part of the ions contained in the aqueous phase are consumed. Then a second peak corresponding to the acceleration period is observed. This peak is complex as it contains obviously several components indicating several chemical reactions involved. Finally the electrical conductivity increases more slowly and to lower values to end as a plateau. Globally the presence of iron does not change the general shape of the electrical conductivity curve but some points can be mentioned. It seems that the dissolution rate of Ye'elimite is slightly reduced in the presence of greater amounts of iron: lower value of electrical conductivity at the maximum of the first and second peaks and slower rise thereafter. Complementary experiments would have to be carried out in order to analyze the aqueous phase composition in order to demonstrate this hypothesis as the electrical conductivity depends on the concentration of ions in solution and on their specific conductivity. As the specific conductivity of aluminate ions is higher than the one of iron ions, if iron ions replace aluminate ones, the electrical conductivity should drop. Nevertheless iron ions are generally not accumulated into the aqueous phase due to the low solubility of iron containing phases. The induction period becomes also slightly longer when the concentration of iron increases in the calcium sulfoaluminate phase. Thus the presence of iron would have an effect on the nucleation of hydrates such as gibbsite during this period.

These results carried out on suspensions are constituent with the experiments on paste obtained by calorimetry but they provided some additional information. Nevertheless it can be concluded that the presence of small quantities of iron in Ye'elimite slightly slows down its reaction rate but also slightly increases the percentage of reaction, without changing the hydration mechanism. Higher percentage of iron may lead to different conclusions especially as $\mathrm{C}_{2} \mathrm{~F}$ phase is also formed along Ye'elimite in high amounts. 


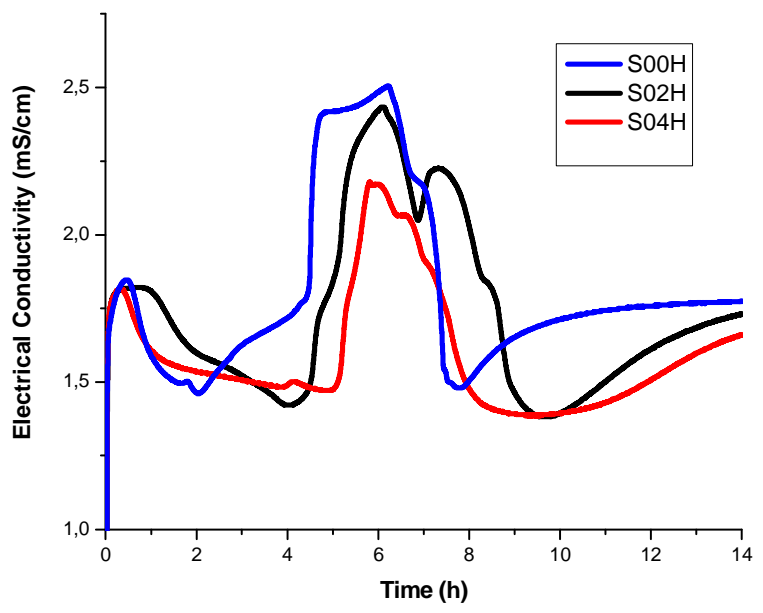

Fig.3. Hydration conductivity curves of the S0OH, S02H and S05H samples.

\subsection{X-Ray Diffractions}

Figure 4 reports XRD patterns for the hydrated pastes $\mathrm{S} 00 \mathrm{H}, \mathrm{S} 02 \mathrm{H}$ and $\mathrm{S} 05 \mathrm{H}$ after 24 hours of hydration. All samples indicated the formation of the same hydrates as suspected from calorimetric and conductimetric experiments: ettringite, of calcium monosulfoaluminate hydrate and of Gibbsite. The identification of these phases after one day of hydration is in agreement with the literature. Moreover $\mathrm{C}_{3} \mathrm{AH}_{6}$ (identified using the reticular distance $7.66 \AA$ ) has also been identified. This hydrate has been sometimes reported [25] and could be explained by some local depletion of sulfate. Indeed the absence of the peaks corresponding to Ye'elimite indicates that it had completely reacted after one day. The formed hydrates, ettringite and monosulfoaluminate, of sulfoaluminate iron doped phases show a more crystalline character than the undoped phase.

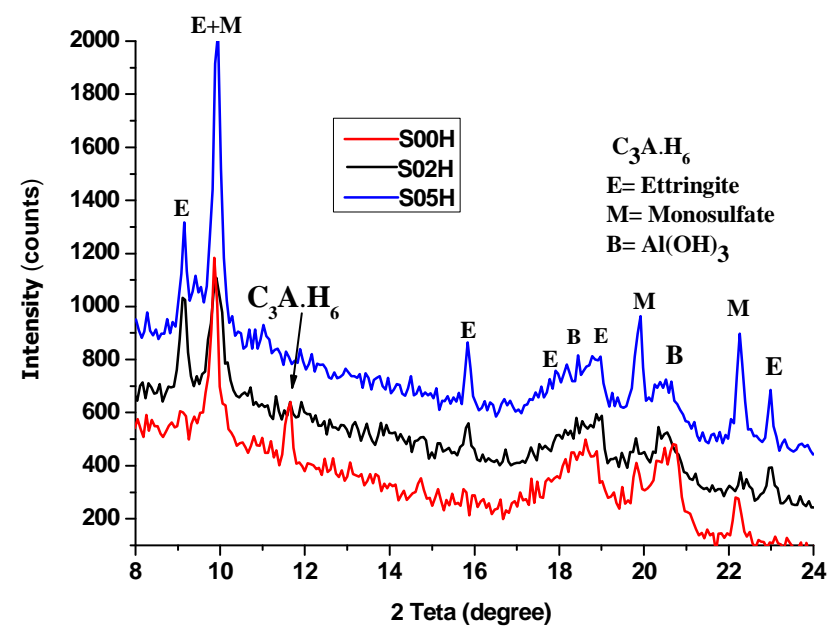

Fig.4. X-ray diffraction patterns of hydrated samples $\mathrm{S} 00 \mathrm{H}, \mathrm{S} 02 \mathrm{H}$ and $\mathrm{S} 05 \mathrm{H}$ at $24 \mathrm{H}$.

\subsection{Scanning Electron Microscopy}

Figure. 5 shows the observed phases by Scanning Electron Microscopy on the hydrated samples after 24 hours, at a magnitude of $800 \mathrm{X}$. We clearly observed the formation of hydrated phases, Ettringite, calcium monosulfoaluminate and iron-rich phase with grain size relatively small and dispersed on the sample area. The corresponding zones are respectively indicated by zones 1,2 and 3.

The precise analyses of these three areas, with higher magnification, are shown respectively on Figures 6, 7 and 8. The figure. 6 shows Ettringite in the form of long needles, whose chemical composition is measured by EDAX analysis. The morphology of hexagonal plates arranged forms of calcium monosulfoaluminate hydrate were also 


\section{INVACO2}

clearly identified as shown in Figure 7. The presence of small quantities of iron is observed in the two phases. In figure 8 is reported the micrograph of the sample S05H hydrated after 24 hours, at two magnitudes 2500 and 8500 , it shown the microstructure of the ferritic phase. The EDAX analysis exhibits the presence of sulfur amounts in this phase at approximate proportion: $(\mathrm{CaO})_{2.6}\left(\mathrm{Al}_{2} \mathrm{O}_{3}\right)_{0.66}(\mathrm{FeO})_{0.075}\left(\mathrm{SO}_{4}\right) \mathrm{O}_{9.3}$.

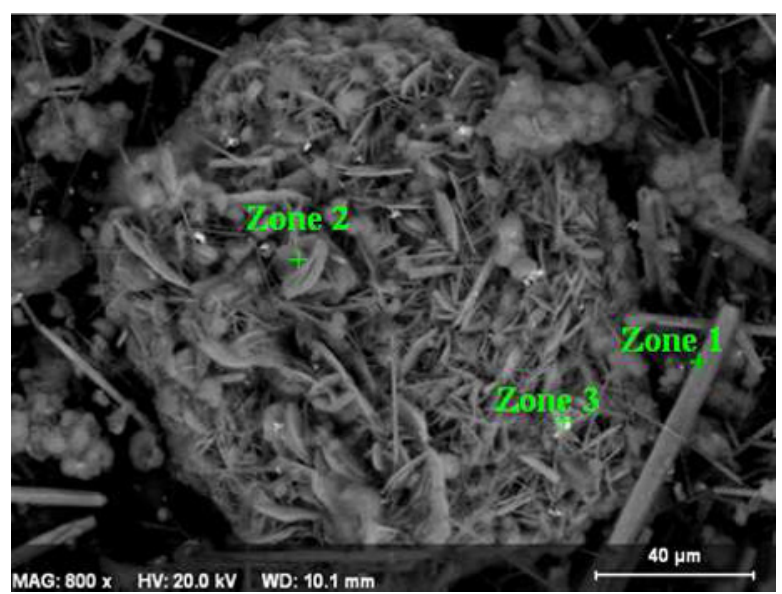

Fig.5: SEM micrograph of S05H after 24h of hydration: showing formation of ettringite in Zone 1", monosulfoaluminate in "Zone 2" and ferritic phase in "Zone 3".
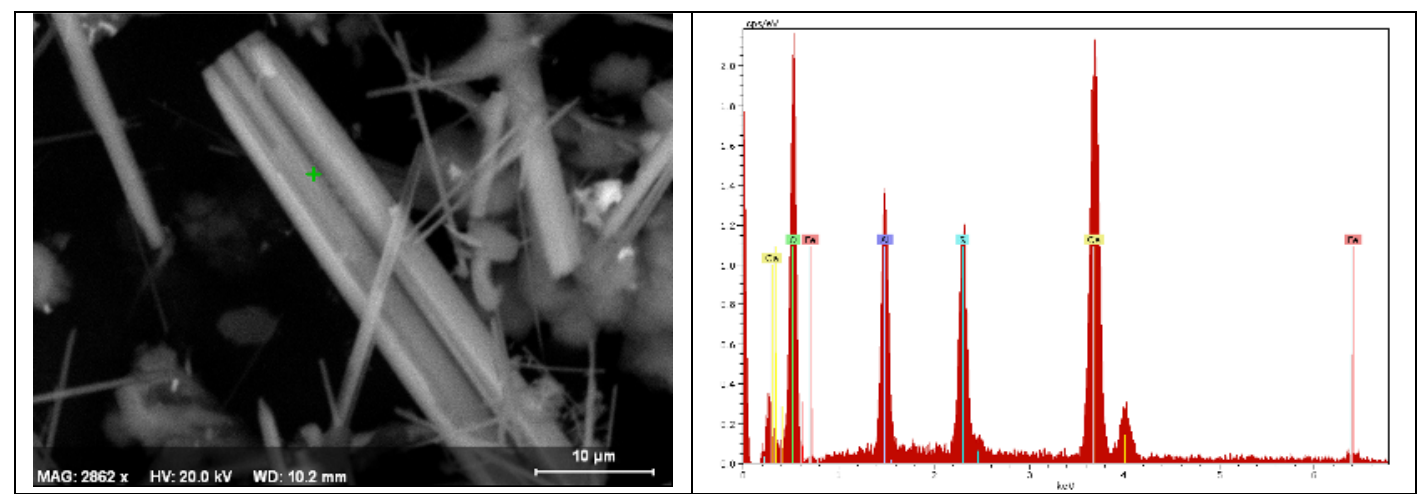

Fig.6. SEM micrograph of S05H at 24h: EDAX analyses of "zone 1" zoom.

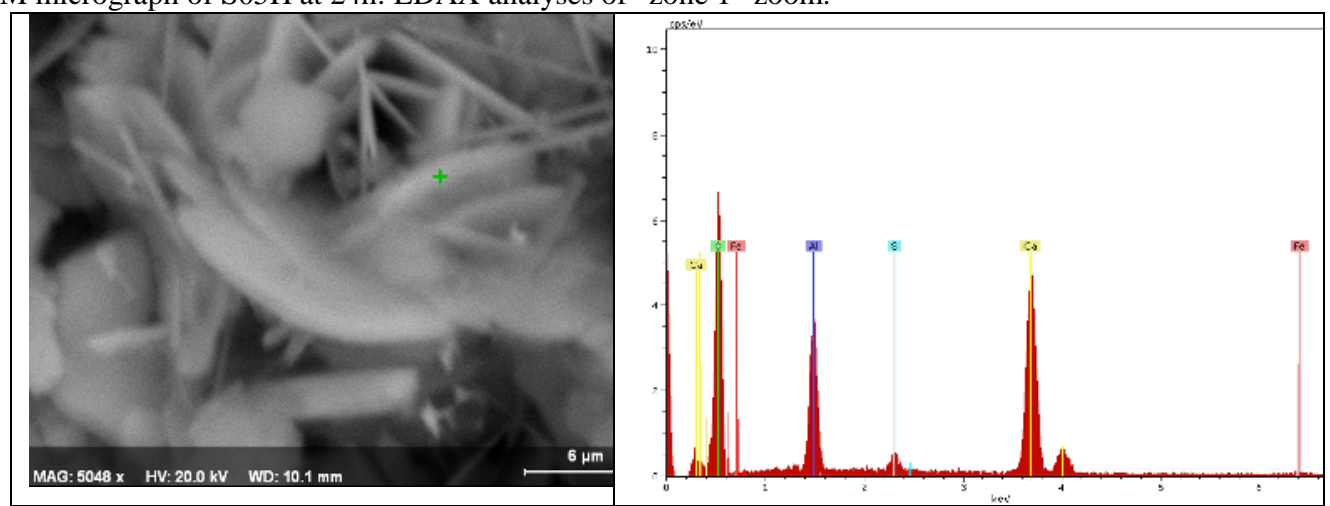

Fig.7: SEM micrograph of S05H at 24h: EDAX analyses of "zone 2" zoom. 


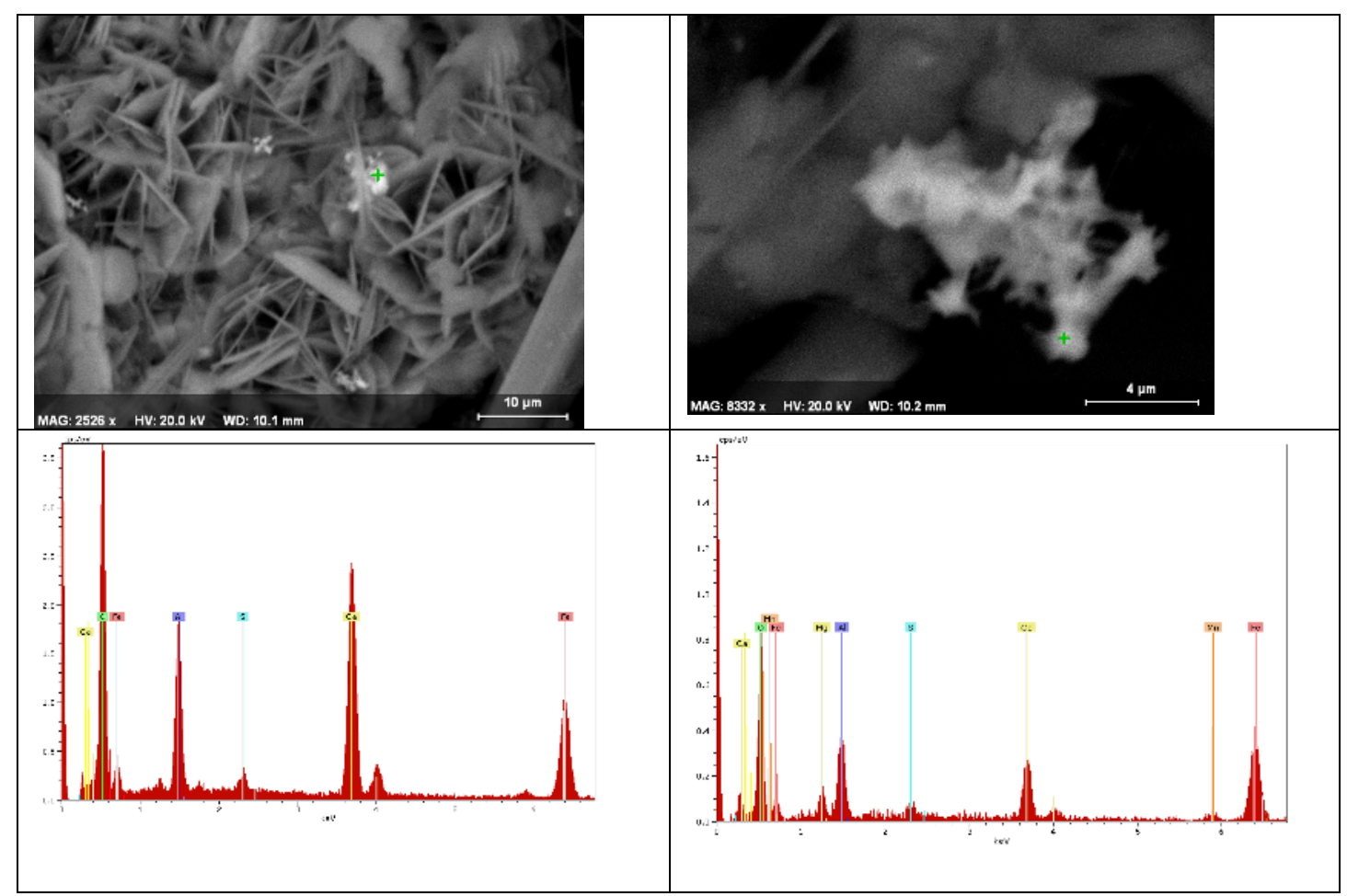

Fig.8. SEM micrographs showing the microstructure of ferritic phase in S05H sample hydrated after 24h: EDAX analyses of "zone 3" zoom.

\section{Conclusions}

Calcium sulfoaluminate phase doped with iron, $\left(\mathrm{Ca}_{4} \mathrm{Al}_{(6-2 \mathrm{x})} \mathrm{Fe}_{2 \mathrm{x}} \mathrm{SO}_{16}\right)$, with low content of iron $(\mathrm{x} \leq 0.5)$ have a similar behavior as Ye'elimite. The same major phases are found after 1 day of hydration but they contained small amount of iron: AFt, AFm and $(\mathrm{A}, \mathrm{F}) \mathrm{H}_{3}$. Doping calcium sulfoaluminate with iron seems to slightly reduce the dissolution rate and also the nucleation rate during the induction period whereas the percentage of reaction after 1 day was slightly increased. The low sensitivity of Ye'elimite to iron substitution is important to produce robust CSA cement with different raw materials and amongst them some by-products. However this may not be the same for high iron replacement leading to the formation of high amounts of $\mathrm{C}_{2} \mathrm{~F}$ along with iron substituted calcium sulfoaluminate phase as this former phase has a quite low reactivity.

\section{Acknowledgements}

The authors would like to thank EGIDE for the financial support given by the grant $\mathrm{N}^{\circ} \mathrm{MA} / 05 / 119 \mathrm{~F}$ in the framework of a France-Morocco exchange program.

\section{References}

1. W. Yanmou, S. Muzhen. Sulphoaluminate cement. Beijing University of technology publishers. (1999), p. 12

2 J. Beretka, N. Shermamn, M. Marroccoli, A. Pompo, GL. Valenti. Effect of composition on the properties of rapid hardening sulfoaluminate cement. In: Justnes HJ, Amarkai AB, Congrex, editors. 10th International congress on the chemistry of cement, vol. 2, June 2-6 (1997). p. 2ii029, 8.

3 V. Kasselouri, P. Tsakirids, Ch. Malami, B. Georgali, C. Alexandrio. A study of the hydratation products of a non-expansive sulfo-aluminate cement. Cement Concrete Res 25 (8), (1995), pp 1726-36.

4 V. Zivica. Properties of blended sulfoaluminate belite cement. Construct Build Mater, 14, (2000), pp $433-437$.

5 AK. Chatterjee. Special cements. In: Bensted J, Barnes P, editors. Structure and performance of cements. Spon Press, (2002), p. 226-231.

6 I. Odler. Cements containing calcium sulfoaluminate. In: Bentur A, Mindess S, editors. Special inorganic cements. E\&FN Spon, (2000). pp. 69-87.

7 M. Su, W. Kurdowski, F. Sorrentino. Development in non-Portland cements. In: $9^{\text {th }}$ international congress on the chemistry of cement, New Delhi, India, vol.1, (1992). pp 317-54.

8 FP. Glasser, L. Zhang. High-performance cement matrices based on calcium sulfoaluminate-belite composition. Cement Concrete Res. 31, (2001), pp 1881-1886. 


\section{INVACO2}

9 K. Quillin, Performance of belite-sulfoaluminate cements, Cement Concrete Res. 31 (2001), pp 1341-1349. 10 S. Brooks, J.H. Sharp, Ettringite-based cements, in: R. Mangabhai, Calcium Aluminate Cement, Spon, London, (1990), pp. 335-349.

11 J.H. Sharp, C.D. Lawrence, R. Yang, Calcium sulfoaluminate cements-low-energy cements, special cements or what? Adv. Cement Res. 11, (1999), pp 3-13.

12 L. Zhang, M. Su, Y. Wang, Development of the use of sulfo- and ferroaluminate cements in China, Adv. Cement Res. 11, (1999), pp 15-21.

13 I. Kapralik, F. Hanic. Phase relations in the sub_system $\mathrm{C}_{4} \mathrm{~A}_{3} \mathrm{~S} \sim \mathrm{S} . \mathrm{H}_{2} \sim \mathrm{H}_{-} \mathrm{H}_{2} \mathrm{O}$ of the system $\mathrm{CaO}-\mathrm{Al}_{2} \mathrm{O}_{3} \sim \mathrm{S}-$ $\mathrm{H}_{2} \mathrm{O}$ referred to hydration of sulphoaluminate cement. Cem. And Conc. Res. 19, (1989), 89-102.

14 F.Hanic, 1.Kapralic and A. Gabrisova, Cem. Concr. Res. 19, (1989), pp 671.

15 J.Havlica, S.Sahu, Cem. Concr. Res. 22, (1992), pp 671.

16 V.Kasselouri, P.Tsakiridis, Ch.Malami, B.Georgali, C.Alexandridou, Cem. Concr. Res. 25, (1995) , pp 1726.

17 G. Bernardo, A. Telesca, G.L. Valenti, A porosimetric study of calcium sulfoaluminate cement pastes cured at early ages, Cem. Concr. Res. 36 (6), (2006), pp 1042-1047.

18 L. Zhang, F.P. Glasser, Hydration of calcium sulfoaluminate cement at less than 24 h, Adv. Cem. Res. 14 (4), (2002), pp 141-155.

19 L. Zhang, F.P. Glasser, Investigation of the microstructure and carbonation of CSA- based concretes removed from service, Cem. Concr. Res. 35 (12), (2005), pp 2252-2260.

20 M. Marroccoli, F. Montagnaro, M. Nobili, A. Telesca, G. L. Valenti, Hydration properties of calcium sulphoaluminate cements made from coal combustion wastes, Proceedings of the $30^{\text {th }}$ Meeting of the Italian Section of The Combustion Institute, (2007), VI.1, Ischia, Italy.

21 M. Idrissi, A. Diouri, D. Damidot, J.M. Greneche, M. Alami Talbi, M. Taibi, Characterisation of iron inclusion during the formation of calcium sulfoaluminate phase, Cement and Concrete Research (2010), doi:10.1016/j.cemconres.2010.02.009

22 Yu R. Krivoborodov and S.V. Samchenko, $9^{\text {th }}$ international Congress on Chemistry of Cement, Proceedings. 3, (1992), 209.

23 F. Winnefeld, S. Barlag. Calorimetric and thermogravimetric study on the influence of calcium sulfate on the hydration of ye'elimite J Therm Anal Calorim, Akademiai Kiado', Budapest, Hungary, (2009), DOI 10.1007/s10973-009-0582-6.

24 M. Doval, M. Palou, V. Kovar. Heat evolution and mechanism of hydration in $\mathrm{CaO}-\mathrm{Al}_{2} \mathrm{O}_{3}-\mathrm{SO}_{3}$ system. Ceram Silik. 49, (2005), pp 104-8.

$25 \mathrm{~W}$. Brameshuber, T. Brockmann. Electrical conductivity measurements to characterize the setting and hardening of mortars. International Symposium (NDT-CE 2003) Non-Destructive Testing in Civil Engineering, (2003). 